DOI: $10.26754 /$ ojs_aem/aem.2019304625

Recibido: $15 / 03 / 2020$

Aragón en la Edad Media

30 (2019) 143-168

Aceptado: 16/04/2020

e-ISSN: 2387-1377

ISSN: 0213-2486

\title{
MEMORIAS DEL ARZOBISPADO DE TARRAGONA (SIGLOS XII-XIII)
}

\author{
THE MEMOIRS OF THE ARCHBISHOPRIC OF TARRAGONA \\ $\left(12^{\text {th }}-13^{\text {th }}\right.$ CENTURIES $)$
}

\author{
María BONET DONATO \\ Universitat Rovira i Virgili \\ maria.bonet@urv.cat
}

Resumen: El arzobispado medieval de Tarragona tejió una memoria sobre su autoridad, revestida de una identidad sagrada, que difundió los caracteres específicos de su potestad y de la realidad dominical. Las tradiciones sobre la sede tarraconense fueron establecidas durante los siglos XII y XIII, con aportaciones destacadas como la del prelado Benet de Rocabertí. Algunos elementos laudatorios y reivindicativos de sus mensajes fueron: la vinculada a la primera cristianización peninsular, la restauración de la Iglesia romana tardía, la reclamación de la primacía, la naturaleza sagrada de algunos obispos, la preminencia en la jurisdicción religiosa y dominical, el reconocimiento del apoyo y patrocinio pontificio

\begin{abstract}
These pages explain the making of an episcopal identity story. The medieval archbishopric of Tarragona wove a specific memory on episcopal authority, that defined a sacred identity, linked to the first Peninsular Christianization and with singular mechanisms of power. This tradition of the episcopal see was constructed contemporary and reinforced in subsequent times. Some key elements of these memories were: the restoration of the late-Roman Church, the sacred nature of the seat and of some bishops, the vindication of metropolitan and 'first' see, the religious authority in the region and against other powers, the recognition of pontifical support and patronage, the
\end{abstract}


y los carismas religiosos. En resumen, el poder del arzobispo se dotó de una ideología que se apoyó en un conjunto de imágenes icónicas al servició de una narrativa legitimadora y para la afirmación de los poderes y las proyecciones de la mitra.

Palabras clave: memoria, historia de la iglesia, historiografía, arzobispado de Tarragona, siglos XII-XIII. links with the major political powers, the religious charismae and the features of lordly power. In short, the archbishop's power was supported by the tradition of the see and drew on a set of iconic images that became a story of legitimacy and authority.

Key words: memory, church history, historiography, archbishopric of Tarragona, $12^{\text {th }}-13^{\text {th }}$ centuries.

\section{La confección de una historia episcopal ${ }^{1}$}

Desde la sede arzobispal medieval de Tarragona se tejió una memoria específica sobre la autoridad episcopal de claro contenido ideológico, que ensalzaba su condición especial y específica en el marco de las relaciones de poder. Los distintos legados escritos de los prelados plenomedievales -en documentos, compilaciones o epigrafía-, contribuyeron a la confección y preservación de dicha memoria, que definía una identidad o potestad de orígenes y naturaleza sacra, sus funciones religiosas, y preponderaba su posición en distintos marcos relacionales, siempre remarcando la legitimidad proporcionada por el papado. Estas consignas e imágenes fueron confirmadas y amplificadas por las tradiciones textuales posteriores de la mitra, a modo de escritura de la escritura. A este respecto, la tradición fijada por los contemporáneos medievales, como la transmitida por el arzobispo Benet de Rocabertí, y la posteriormente elaborada por otros miembros del entorno catedralicio fueron modelando y resaltando rasgos de una autoridad arzobispal concreta, para su afirmación, publicidad y con carácter laudatorio. De este modo, en época moderna, el arzobispo Antonio Agustí, su cercano Pons d'Icart (Icart, 1572, Sánchez, 1954), o posteriormente los canónigos Josep Blanch (Blanch, 1985 [1665], Baró, 2009: 189-193) y Marià Marí, quien sigue a veces a J. Blanch (Marí, 1999 [1783]), produjeron obras o archiepiscopologios que recorrían la sede a través

1 Esta propuesta se ha realizado en el marco del proyecto de investigación: PGC2018-098306-B-I00 y fue presentada como ponencia en el congreso de la Association for Spanish and Portuguese Historical Studies. 50 th Anniversary Conference. Universitat Pompeu Fabra. Barcelona, 10-13 July 2019. Con este trabajo nos unimos al reconocimiento de la brillante trayectoria investigadora y académica del profesor Juan F. Utrilla Utrilla. 
de la galería de retratos de sus titulares a modo de genealogías, destacando sus gestas, sus vínculos con otros poderes, que reivindicaban ciertas comprensiones relativas a la tradición de la cátedra, de su poder e identidad. En otro orden de cosas, aunque con una finalidad parecida orientada a resaltar el carisma eclesial de Tarragona, otros canónigos dieciochescos ofrecieron versiones de la historia eclesiástica de la ciudad, como Carlos González de Posada y Félix Amat (Jordà, 2006: 92).

Esta historia sobre la sede tarraconense y su titular se fue configurando por distintas capas depositadas sucesivamente que fueron fijando y desarrollando temas concretos, que trataremos de singularizar en asuntos y tradiciones específicas. En este sentido, analizaremos el peso que tuvieron argumentos como la restauración de la Iglesia tardorromana, la condición primada o metropolitana, la autoridad religiosa en la región y frente a otros señores, el reconocimiento de la tutela y respaldo pontifical, los vínculos con los principales dignatarios políticos, los carismas religiosos y la potestad señorial, por mencionar ejemplos significativos. En este breve recorrido, que no pretende ser sistemático ni exhaustivo, vamos a dedicar nuestra atención al Códice AB del Archivo Archiepiscopológico de Tarragona, conocido como el cartulario de Benet de Rocabertí (1252-1268). El arzobispo se preocupó de reunir en un magnífico volumen de pergamino copias de misivas pontificales, instrumentos de sus relaciones con los miembros del capítulo, con el rey y relativos a la administración eclesial, entre otros. Obedecía a la necesidad de fijar los derechos de la sede, de la cátedra arzobispal, en un momento convulso (Morera, 1954: 7682), aunque bajo el liderazgo de un prelado carismático y reformador. El afianzamiento de dicha memoria a partir del manuscrito respondió al periodo clave de la reivindicación, y en cierto modo, de consolidación de su autoridad.

Sin embargo, es oportuno recordar que este volumen no fue elaborado de una sola pieza puesto que además de los documentos del mandato de Benet de Rocabertí, reúne instrumentos que van del siglo XII hasta principios del XIV en la segunda parte, siendo el más tardío del año 1314. La propia arquitectura del libro así lo señala y hay dos índices de los diplomas en las páginas iniciales, separando aquellos que van desde la página 92 , a saber, los de la segunda parte $^{2}$ de los que llegan a la 91 de la primera. ${ }^{3}$ La primera mitad originaria contiene documentos institucionales vinculados al arzobispado mencionado, mien- 
tras que la otra refiere cuestiones de carácter patrimonial, de algunas localidades y bienes del dominio de la mitra, que en algunos casos fueron copiados por notarios a finales del siglo XIII. El hecho que se añadiesen a este códice podría sugerir que fue entendido y visto como un recuento de documentación que legitimaba los derechos de toda índole del poder mitrado, como sucedió con la cuestión de la castellanía de Riudoms estudiada por Jordi Morelló (Morelló, 2018). El libro era en sí mismo una fuente de tradición y legitimación, que, por otra parte, mantuvo coherencia formal pese a los diversos momentos de su compilación.

\section{Tradición de una sede restaurada. De mártires a santos y la vinculación al papado}

En la tradición de la sede tarraconense fue muy importante el reconocimiento y realce del obispo de Barcelona, Oleguer, quien la restauró. Algunos elementos que reseñar son la redacción y reconocimiento como santo en la vida y milagros escrita en torno a 1140 (Flórez, 1775: 475, Aurell, 1999: 8790), su reconocimiento semihagiográfico como obispo cruzado y reconstructor de iglesias en Tarragona, concretamente de las obras de la catedral. Los archiepiscopológicos de P. d'Icart o de J. Blanch se hicieron eco de esta iniciativa (Sánchez, 1954: cap. 26, Blanch, 1985: 82), que formaría parte del relato hagiográfico (Mc. Crank, 1978: 174).

La restauración estuvo muy determinada por un estrecho vínculo con el papado porque la ideología de la restauratio se desarrolló con la propuesta reformista, que asignaba un lugar preferente al pontífice (Mc. Crank, 197677: 5-6) y la reactivación de los poderes diocesanos. De hecho, Urbano II había dirigido sendas misivas al conde de Barcelona y al obispo de Vic, en 1089 y 1091, para iniciar la restauración de Tarragona. La carta dirigida a Berenguer Sunifredo dedicaba la iglesia tarraconense a santa Tecla, y se indicaba que junto a san Fructuoso serían los patrones de la ciudad (Bonet, 2011: 73). En la donación de Tarragona a Oleguer por el conde de Barcelona, Ramón Berenguer III, en 1118 para la restauración, manifestó la exaltación de la Iglesia y de Pedro, príncipe de los apóstoles, explicitándose la especial relación con la cátedra romana (Font Rius, 1969: doc. 49). Estos nexos con la sede petrina pueden relacionarse con las informaciones relativas a que Oleguer y posteriormente su vasallo, el normando Roberto Bordet, fueron a 
Roma (Blanch, 1985: 82, Aurell, 1999: 88 y Chibnall, 1978: 404), lo que refleja la dependencia y amparo del pontificado como elementos definitorios de la tradición surgida en torno a la restauración. Por otra parte, cabe destacar, que el instrumento de 1118 fue asumido como principal en la historia de la ciudad y del arzobispado, por lo que fue trasladado a lo largo del tiempo y por distintas instituciones, como hiciese la cancillería regia, ${ }^{4}$ la municipalidad de Tarragona en 1336, ${ }^{5}$ o copiado por el canónigo Blanch (Blanch, 1985: 80-81). El diploma tuvo un valor fundacional y, en general, la restauración también lo tuvo como punto de partida de todos los desarrollos ulteriores.

La narrativa sobre la restauración eclesiástica se forjó en distintas cancillerías y momentos, que compartieron la voluntad de señalar y enfatizar el abandono que la ciudad había padecido tras la conquista islámica. En este sentido, cabe preguntarse por qué se hacían evidentes los años de despoblado, que se fijaron en trescientos noventa años en la bula de Urbano II de 1091. Este documento fue muy apreciado en la historia episcopal, y fue trasladado como uno de los primeros registros en el Llibre de la Corretja del siglo XVI, ${ }^{6}$ donde se reunieron diplomas medievales principales para la preservación de la memoria de la mitra. En otras referencias textuales, se indicaba que los musulmanes no habían permanecido en la urbe y ello, unido a la idea del despoblado, subrayaba el carácter únicamente cristiano de la misma. También Ramón Berenguer III, en la donación de Tarragona a Oleguer, la definió como lugar destruido y yermo. Este pasado de vacío, exagerado y no aplicable a todo el período parecía contener dos mensajes: el primero que la condición cristiana no había sido corrompida por los musulmanes; y, el segundo, que Oleguer consiguió y, en cierto modo, encarnó la restauración eclesiástica. El cronista normando Orderico Vitalis también prestó atención a la restauración eclesiástica conducida por el obispo de Barcelona, en contraposición con la falta de autoridad anterior. Su texto lo expresó metafóricamente al describir el estado de abandono de la basílica episcopal, donde habían crecido árboles y que relacionaba con la expulsión de los visigodos por los musulmanes (Chibnall, 1978: 403).

Por otra parte, el nexo con la primera iglesia de Tarragona, así como con el papado, fueron ejes de la construcción de la memoria de la sede recuperada en 
el siglo XII. En relación con los orígenes, fue manifiesta la voluntad de ligarse con los primeros santos patones, como Tecla, y con el mártir local, el obispo Fructuoso (258/259). El texto martirial ha sido considerado el de mayor valor histórico sobre los inicios del cristianismo en Hispania (Pérez, 2012: 59). En la mencionada dotación del conde de Barcelona se recordaba que la sede había sido fundada in honore beatae Tecle virginis y pronto hubo en la ciudad una iglesia con dicha advocación (Villanueva, 1850-1852: 275). Cabe recordar la vinculación de la santa al apóstol san Pablo y la consiguiente proyección del carisma apostólico en la sede tarraconense. En este contexto, una más que probable leyenda indicaba que Oleguer había celebrado misa en el anfiteatro donde había padecido martirio el santo tarraconense, estableciendo una relación entre dicho lugar icónico del primer cristianismo y la resurrección de la Iglesia justamente a través de este primer arzobispo restaurador. El santo-mártir, seguramente el más antiguo de la Península, era la fuente de legitimidad de la restauración de la Iglesia triunfante. Poco después de la ocupación de la ciudad, se levantó una nueva iglesia, donde había habido una martirial visigoda en la arena del anfiteatro, conocida como Santa María del Milagro (Mansi1la, 1955: 108-111 (1154).

En realidad, la dinámica de la restauración fue muy compleja y alejada del relato victorioso sobre el primer obispo restaurador, quien todo apunta a que no pudo acceder a la cátedra y difícilmente estuvo en Tarragona. Las fuentes hagiográficas y otras eclesiásticas trataron de conceder un papel destacado al prelado restaurador quien, en cambio, no fue capaz de llevar a cabo la ocupación feudal de Tarragona y su territorio y en 1129 tuvo que confiar tal tarea al príncipe Roberto Bordet. Esta situación complicó mucho el afianzamiento del poder eclesial en las décadas centrales del siglo XII. Sin embargo, el episodio también formó parte de la memoria de la sede, como refleja el retablo de 'san Oleguer' en la catedral de Tarragona efectuado por Francesc Bonifàs en 1776, con una evidente posición de genuflexión por parte del normando, auténtico recuperador de la ciudad frente a Oleguer. Un escriba de la curia - y en un plano intermedio entre los dos protagonistas - , completa la imagen, quien tomó nota y legitimó el acto, en clara referencia a la importancia de los registros escritos a la hora de fijar las relaciones entre los mandatarios de la urbe recién ocupada.

A pesar de su incapacidad por dominar la ciudad, el mencionado Oleguer fijó ideas fundamentales del discurso referente a la potestad de la sede de Tarragona. En este aspecto, evocó la restauración y la condición metropolitana de la misma hecha por los pontífices Gelasio II y Calixto II en la concesión de 
Tarragona a Roberto Bordet, si bien recordaba la donación que le había hecho el conde Ramon Berenguer III (Font Rius, 1969: doc. 51). La reivindicación del papado como fuente de autoridad, e incluso de la condición metropolitana estaba presente en la construcción de una identidad diferenciada, que se alejaba de la autoridad condal y adquiría un carisma superior, incluso a nivel peninsular. El mismo Oleguer se situaba al frente de la Hispania Citerior recuperando un esquema provincial anterior y de mayor entidad que la propia tarraconense, con cierto posible rechazo a la primacía toledana (Faci, 1991: 482). Esta idea hispana estaba en el ambiente de la restauración y ocupación de la capital ya que el conde de Barcelona se autodenominó marchio hispaniarum al infeudar Tarragona a Oleguer.

Otra figura notable en la memoria reconstruida de la sede episcopal fue Hug de Cervelló (1164-1171), arzobispo en tiempos convulsos que murió asesinado por la familia de los vasallos Bordet. Según reseñó el cardenal Baronio en el martirologio romano, su muerte tuvo lugar en el mismo año que la de Tomás Becket, mártir a manos del rey y beatificado poco después, como recogía el canónigo Blanch (Blanch, 1985: 102). Refirió una lectura que procedía de altas esferas romanas según explicitaba, que integró en el mensaje difundido desde la escribanía tarraconense. Este paralelismo era expresivo del carácter cuasi martirial del mitrado, que el canónigo Marí recogió con estos términos:

Hugo havent imitat Tomàs de Canterbury, que lluitava per la jurisdicció i la llibertat de l'Església [...] i deixà a la seva posteritat exemple i testimoni [...] de fe. (Marí, 1999: 41).

Además, el epitafio de la tumba del arzobispo Hug de Cervelló recordaba que fue asesinado por su vasallo, el príncipe de Tarragona y que por ello su familia había sido expulsada de todo el reino: per edictum regium expulsi, sed et bonis suis priuati (Blanch, 1985: 102 y Marí 1999: 41). El mensaje se articulaba acompañado de las bulas de Alejandro III - también custodiadas en la sede de Tarragona-, que avalaban la necesidad de expulsar y despojar del dominio a los normandos (Blanch, 1985: 100-101, Marí, 1999: XI y XIII). Asimismo, en el manuscrito Thesaurus sanctae metropolitanae ecclesiae Taraconensis, redactado por el mencionado canónigo Marí en 1783, también se compiló la bula papal destinada al rey por el asunto: ab mortem Hugoni archiepiscopo violenter inflictam. ${ }^{7}$ A la par, la idea de martirio fue muy pode- 
rosa y entroncaba con la tradición mencionada sobre el obispo Fructuoso, que en cierto modo compartía Tecla, y que a través del asesinato del arzobispo Hug podía vincular con otros santos, como el primado de Inglaterra. En este caso se había establecido una analogía, que finalmente justificaba la expulsión de los culpables y la privación de sus bienes. El asunto era de tal importancia que quedó gravado en piedra para siempre en la tumba de Hug de Cervelló. La memoria oficial del entorno episcopal se esforzó por dejar patente que los Bordet desaparecieron del dominio tarraconense, con quienes el prelado había mantenido una intensa lucha y quedaba justificado de forma definitiva por el gran oprobio del asesinato. Esto no sucedió según lo previsto ni conforme a lo reseñado en estas fuentes eclesiásticas y, en cambio, el linaje mantuvo derechos y presencia en el ámbito tarraconense, aunque terminaron desapareciendo pasadas unas décadas (Bonet, 2011: 108).

En el peso de la tradición sobre la santidad asociada a la figura del arzobispo, es oportuno mencionar a Juan de Aragón, arzobispo de Tarragona (13271334), hijo de Jaime II, a quien se reconoció como beato: mori aquest arquebisbe ad opinió de sant (Blanch, II, 1985: 38) o en otros términos famós pels seus miracles (Marí, 1999: 88). Nos fijaremos en el discurso que se despliega en su magnífico sepulcro. Se tarta de un programa iconográfico muy cuidado, en el que los santos patrones, Tecla y Fructuoso, acompañaban al difunto, así como otros santos miembros de la estirpe de su madre, Blanca de Anjou, como san Luís de Anjou o de Languedoc, obispo de Tolosa, hermano de Blanca, san Luís rey de Francia o santa Isabel de Hungría. Es posible plantear que el arzobispo encarnaba la progresiva 'sacralización' de la casa de Aragón y que ello se había logrado, en buena medida, debido a su posición al frente de la sede de Tarragona. El conjunto monumental se aloja en el sancta sanctorum de la catedral, junto al altar, y está presidido por las reliquias de santa Tecla, que llegaron a la ciudad por mediación de los embajadores de su padre. Por otra parte, el epitafio destacaba que era hijo de Jaime II, que había sido arzobispo de Toledo a los diecisiete años, patriarca de Alejandría y administrador de la Iglesia tarraconense desde los veintiocho. Finalmente, se decía que había obrado milagros en vida y después de muerto. El difunto reunía el carisma de la sede tarraconense y de la ascendencia santa de la realeza francesa. Cabe recordar que gracias a la alianza de Jaime II con Blanca de Anjou se había liquidado el conflicto entre Aragón y el papado. Santidad personal, santidad familiar y de la sede tarraconense servían para revestir de excepcionalidad una figura, el cargo arzobispal, y la propia estirpe, arropada por la Iglesia y en la 
sede arzobispal (Bonet, 2011, 128-131). Dicha voluntad encajaría con el hecho que seguramente el arzobispo Arnau Sescomes, uno de sus albaceas, hubiese sido el ideólogo de esta sepultura monumentalizada (Español, 2018). Otros contextos locales y políticos, como los cambios en la metropolitanía en 1318, permiten también explicar la exaltación de la santidad del prelado de Tarragona en la persona de Juan de Aragón.

Como se ha advertido, la vinculación a Roma fue un elemento primordial en la memoria episcopal y en la relaboración de esta desde sus escribanías, donde se fueron copiando bulas que avalaban la restauración y los ajustes posteriores (Marí, 1999: II, III, VIII, XI, XII, XIII, etc.). Todo ello estaba relacionado con otros elementos como la condición de capital provincial romana ya mencionada, la condición martirial de Fructuoso y la carta del papa Siricio al obispo Himerio de Tarragona (385). Bajo las instrucciones pontificales, Himerio debería trasladar al resto de obispos hispanos los contenidos de la misiva, básicamente un código general de disciplina eclesiástica (Pérez, 2012: 77 93), reflejándose la condición primera de esa diócesis con relación a las otras. Posteriormente, la bula de Urbano II de 1091 para la restauración se denominó Inter Primas Hispaniarum urbes.

Todos estos aspectos estaban en el trasfondo de la reivindicación de la sede primada, a la que no renunciaron sus titulares. Se reclamó en concilios a lo largo de los siglos XII y XIII, planteándose para la Hispania Citerior (Flórez, 1770: 162-167) y se mantuvo en la tradición eclesiástica local a lo largo de los siglos. El papado revitalizó la provincia eclesiástica de la Tarraconensis, estableciendo sus derechos metropolitanos sobre las sedes de Girona, Barcelona, Urgell, Osona, Lleida, Zaragoza, Huesca, Pamplona, Tarazona y Calahorra en 1154 (Mansilla, 1955: doc. 92), pero obligó a su titular a reconocer al arzobispo de Toledo como primado bajo amenaza de privarle de palio (Mansilla, 1955: doc. 94), recordándoselo en ocasiones posteriores (Mansilla, 1955: docs. 95, 117, 125). Por tanto, el pontífice defendió los derechos primados de Toledo. Además, con posterioridad, se produjeron cambios en la autoridad tarraconense derivados de la obtención de la condición arzobispal por parte de Zaragoza en 1318 (Goñi Gaztambide, 2010). Con todo, en la tradición moderna de los archiepiscopologios se siguió reivindicando la condición primada, como se evidencia en el título de la obra de J. M. Blanch, Arxiepiscopologi de la santa església metropolitana i primada de Tarragona. La idea de la primacía continuó formando parte de la tradición y memoria sobre la cátedra tarraconense y sus eclesiásticos siguieron reclamando dicha condición al referirse a la misma como 
J. T. Bessa, Sermon panegyrico de la glorosissima protohomartyr Santa Tecla, predicado en la Iglesia Cathedral de Tarragona, Ilustre Primada de las Españas en 1718 (Perea, 2007: 197 y otros ejemplos modernos y contemporáneos 101, 102 y 199). Incluso el término de sede primada ha sido utilizado por historiadores eclesiásticos próximos a la catedral como el destacadísimo J. Serra Vilaró (1934) y P. Batlle Huguet (1946).

\section{Guillem de Montgri, ¿archebisbe de Tarragona, obispo electo (1233-1239) o sacristán de Girona?}

Entre las figuras y momentos del arzobispado plenomedieval cabe fijarse en Guillem de Montgrí y, en particular, en cómo y por qué fue reseñado en memorias posteriores. En la tradición de los archiepiscopologios fue reconocido como arzobispo o obispo electo: don Guillem de Montgrí archebisbe de Tarragona (Blanch, 1985: 143). Con todo, en la descripción de Blanch se especificaba que sólo fue arzobispo electo y que jamás quiso aceptar la prelatura, aunque insistía en las buenas obras que había hecho para la sede. También Marí expuso que permaneció sólo como electo, con el consentimiento pontifical (Marí, 1999: 58). En el registro de documentos de la sede —índex Vell-, la versión sobre él es: Guillem de Montgrí, qui conqueri Eivissa i mai se volgué consagrar com arquebisbe, aunque mencionado como bisbe electe (Ramon, Ricomà, 1997: 120, doc. 450 y 122). En fuentes de ideario diferente, como en la crónica de Bernat Desclot, Guillem de Montgrí era identificado como arzobispo: com respòs l'arquebisbe de Tarragona (Soldevila, 1983: XV, 422), si bien en un sentido más bien genérico.

Este sacristán de la catedral de Girona participó en la conquista de Ibiza con su pariente Bernardo de Santa Eugenia y aunque obtuvo una parte, más tarde amplió su dominación sobre las islas, comprando a título individual la de Nuño Sanç y la del infante de Portugal. En sus últimas voluntades dejó Ibiza y Formentera a la sede de Tarragona en 1247; haciéndose efectivo el legado tras su muerte en 1273. El testamento y el codicilo se copiaron en el códice de Benet de Rocabertí de forma íntegra, reconocido como sacristán de Girona; se había previsto que siempre arderían cinco velas frente al altar de santa Tecla, y se registró bajo el epígrafe: testamentum G. de Montegrino, sacriste Gerundensis. ${ }^{8}$ Marí especificó en el recuento sobre este obispo elec- 
to que su legado testamentario y los codicilos se habían escrito en $1247 \mathrm{y}$ 1248 (Marí, 1999: 60); detalles, por otra parte, que no ofrecía sobre los momentos finales de otros arzobispos. Por tanto, el destino de su herencia quedó bien explicitado en una fuente confeccionada años más tarde y recordada siglos después.

$\mathrm{Su}$ trayectoria personal y el mismo testamento reflejan que actuó como un señor más en su contribución en la empresa de las Pitiusas, y que entendió que le correspondía por derecho de conquista. Según el Llibre dels feyts, Guillem de Montgrí propuso al rey Jaime I que le diera Ibiza en 1234, denominado como arzobispo electo; y se explicitaba que elet per arquebisbe de Tarragona: que ell ab son llinatge la conqueriria, e pus nós no l'haviem - decía el rey-, e haviem altres coses a fer, que ben deviem voler que ell la conquerís, per ço que hom digués que l'arquebisbe de Tarragona havia conquerida Eivissa, e ell la tenria per nós (Soldevila, 1983: 125, 62). De hecho, mientras Guillem vivió, disfrutó de los bienes conquistados, que probablemente nos permite explicar por qué Marí registró una constitución impulsada por el arzobispo electo, denominada Cum humana fragilitatis. El y los canónigos establecieron que el prelado y otras dignidades capitulares, que por «causas honestas», quisieran dejar sus cargos, dispondrían de lo que habían acumulado con «su esfuerzo y trabajo» mientras viviesen y tras su defunción dichos bienes y ganancias revertían en el nuevo titular del cargo (Marí 1999: 58-59). Marí recogía una información que, por una parte, reflejaba el interés de utilizar privadamente el patrimonio alcanzado por parte de Guillem de Montgrí y, por otra, advertía que el destino final del mismo debía ser el 'retorno' al dominio eclesial. Era una especificidad que, junto a la mención al legado testamentario en su archiepiscopologio, estaban fijando la legitimidad del señorío sobre el destacado dominio de Ibiza por parte del arzobispado de Tarragona.

Estos datos y la presentación de la situación en textos contemporáneos y posteriores generan algunas cuestiones: ¿por qué no aceptó el cargo y renunció en 1239? ¿aspiraba a que los bienes conquistados terminasen en sus manos y las de su linaje? En todo caso, diversas fuentes - y no procedentes de la sede tarraconense- - como la misma crónica de Jaime I reivindicaban la condición de Guillem de Montgrí como figura ligada a la mitra y que era el origen de los derechos que aquella terminó disfrutando en Ibiza. De hecho, una bula de Gregorio IX especificaba que a su muerte y tras disfrutar de los derechos, revertiesen en la iglesia tarraconense: et post obitum tuum castra, 
insula et uilla prefata libere ad Tarraconensem Ecclesiam reuertatum (Blanch, 1985: 147-148). Es posible que Guillem de Montgrí hubiese previsto mantenerse como señor -él y quizás su estirpe, como hiciese durante su vida - , pero seguramente por mediación del arzobispado, del papado y seguramente del rey, tuvo que ceder. Se trataba, sin duda, de un hombre emprendedor, ambicioso, que también desarrolló actividad como comerciante, que quizás había caído en desgracia frente al papado y que, para Josep Maria Escandell, le habría costado el cargo del arzobispado (Escandell, 2010: 120-122).

Por el contrario, Marc Sureda expone que Guillem de Montgrí gozó del reconocimiento del pontífice, quien aceptó una decisión que probablemente habría sido personal (Sureda, 2010: 201). En todo caso, siempre mantuvo el cargo de sacristán de Girona y recibió sepultura en el claustro de dicha catedral en un extraordinario e inusual sarcófago, aspectos que reflejan su lejanía respecto a la cátedra tarraconense e identificación personal con la gerundense. En 1273, poco antes de morir, actualizó su testamento y codicilo, conservado en el Llibre gran del sagristà major, que, como su epitafio (Marquès, 1970: 31), y su obituario fueron elaborados al servicio de la memoria del cabildo de Girona. El Martirologium ecclesiae Gerundensis (circa 1300) le presentaba como un hombre de Iglesia, que había sido combativo con los herejes siendo electo de Tarragona, conquistador de Ibiza y Formentera por la fe cristiana, fundador de comunidades de regulares y provisor de beneficios para la iglesia de Girona, algunos pagados con recursos del prepósito de Tarragona. Mencionaba derechos del arzobispado, pero detallaba todas las dotaciones a la iglesia gerundense. Por otra parte, se dedicó una oración a su sepulcro en la procesión del claustro (Sureda, 2010: 203-210). La tradición de la catedral de Gerona estuvo interesada en destacar los lazos del sacristán con aquella, que le atribuían una curiosa preponderancia frente a la metropolitana, y sobre todo confirmaban los derechos en beneficio de la diócesis gerundense que debía asumir Tarragona.

En otro ámbito documental, en el códice $\mathrm{C}$ o Liber feudorum del reino de Mallorca custodiado en el Archivo Departamental de los Pirineos Orientales de Perpiñán se registraron varios juramentos de fidelidad del arzobispo de Tarragona y del prepósito al rey de Mallorca. En el juramento del arzobispo Rodrigo Tello a Jaime II por la mitad de las islas de Ibiza y Formentera en 1299, se especificaba que los arzobispos lo habían obtenido del sacristán de Girona, Guillem de Montgrí, quien hizo testamento y juró sobre los evange- 
lios, que a su vez confirmó el rey, salvo retento nobis. En el reverso de la página se copió otro instrumento en el que el rey Jaime I hacía donación a G. per eandem Terrachone electe. ${ }^{9}$ En este traslado, fechado el 7 de diciembre de 1234 , casi un año antes de la conquista, el rey conquistador le ofrecía las Pitiusas, con una relación concreta de las salinas, lezdas y puertos, que era expresiva de los intereses sobre la explotación, y advertía que, si él diese el castillo y las islas a cualquier persona debería facere inde homagium et [...] fidelitatem servare. A tenor de estas previsiones, Jaime I le reconoció como electo, a diferencia de la mención a sacristán en el homenaje arzobispal. Podría tratarse probablemente de un instrumento reelaborado, aunque la finalidad de la copia sería, a nuestro entender, recordar al prelado la razón del vasallaje debido al titular del reino de Mallorca. En posteriores juramentos efectuados por representantes de la sede se siguió manteniendo la referencia a Guillem de Montgrí como sacristán de Girona, como en 1312 o $1313 .{ }^{10}$ Además, esta dependencia vasallática fue objeto de resistencia por parte del arzobispo, como también registró el códice. ${ }^{11}$ No sólo hubo controversia sobre la ascendencia regia en relación con el feudo de Ibiza, sino que, en alguno de los instrumentos, como el de 1312, se mencionaba la parte de Nuño Sanç, que terminó en manos del sacristán Guillem de Montgrí.

Esta documentación procedente de la cancillería del reino de Mallorca de la corte de Perpiñán refleja ciertas problemáticas sobre los derechos de la mitra de Tarragona en Ibiza. Se insistía en el hecho de que habían llegado de parte de Guillem de Montgrí, mencionado como sacristán, quien había obtenido los derechos de manos de Jaime I. Se quería mantener el recuerdo de que estos bienes habían sido originariamente de la corona y habían llegado a Guillem en primera instancia. El traslado de 1234 respondía, por tanto, a las exigencias de recuperar la memoria sobre las condiciones que articulaban los lazos de dependencia y la fidelidad del prelado con el monarca, recordándose expresamente la vinculación vasallática con el rey. Esto concuerda con la explicación de la crónica del Conquistador, que reconocía en Guillem de Montgrí, arzobispo electo, un ejecutor del arzobispado, que tendría la isla en feudo del rey.

En definitiva, la peculiar y atípica situación de un arzobispo escogido, que no llegó a estar al frente de la diócesis, probablemente por intereses

9 Archivo Departamental de los Pirineos Orientales (ADPO), LFc, f. 42 rv.

10 ADPO, LFc, f. 87v-88r y 88rv.

11 ADPO, LFc, f. 89r. 
particulares y familiares, quizás por oposición pontifical, quedó desdibujada en una memoria entrelazada y a veces discordante, que fue formulada por varios discursos. Los diversos enfoques procedentes de la sede de Tarragona, de la cronística regia o de la corte del rey de Mallorca compartieron el cometido de justificar la adquisición de Ibiza por parte del arzobispo o su dependencia vasallática a la monarquía. Sin embargo, en la historiografía actual y como contrapunto a lo visto, se reclama la conquista de Ibiza para «las tierras de Girona», puesto que la «mitad de los hombres que acudieron eran del sacristán mayor de Girona y la repoblación fue casi exclusivamente gerundense» (Escandell, 2010: 129). No ha de sorprender, por tanto, que en la versión de Benet de Rocabertí, el más cercano en todos los sentidos, o más tarde en la corte mallorquina, fuese reconocido como sacristán de Girona, ni tampoco que desde el cabildo gerundense se subrayase dicha vinculación.

\section{Una historia del arzobispado en el códice AB de Benet de Rocabertí y tradiciones posteriores}

En todo el proceso de consolidación de la memoria y tradición de la sede, destaca la contribución del arzobispo Benet de Rocabertí (1252-1268), quien promovió la confección del Códice AB. Se trata de una pieza de excepción para conocer las noticias y documentos que este prelado quiso salvaguardar con ánimo de afirmar los derechos del mitrado e historiar los eventos que protagonizó y afectaron a la cátedra tarraconense. Este conjunto de traslados fue completado en momentos posteriores por otras manos y con criterios semejantes, aunque estos últimos prestaron mayor atención al recuento de los derechos dominicales y feudales. Benet de Rocabertí vivió una situación de máxima hostilidad por parte de los miembros del capítulo (Morera, 1954: 83), mantuvo relaciones difíciles con el rey Jaime I y tuvo proyección en la escena 'internacional'. Algunas de sus acciones recortaron el peso de los canónigos en el gobierno de la sede, que coincidió con su intervención en la definición de las primeras instituciones urbanas municipales (Morera, 1954: 90). Es posible reconocer en sus acciones una preocupación por reformar el clero e intervenir en la organización eclesiástica de la diócesis e iglesias sufragáneas; ello se puso de manifiesto en la organización de tres concilios provinciales en 1253, 1256 y 1266 (Bonet, s. a.). 
Los desencuentros de Benet de Rocabertí con el cabildo catedralicio fueron ampliamente reseñados por J. Blanch, quien censuró al metropolitano, e indicó lo siguiente en la visión de conjunto de su mandato: De aquest archebisbe no.s troben sino plets, qüestions e inquietuts que llansaren a perdre la Iglésia (Blanch, 1985: 159-167). Una lectura muy crítica, aunque también destacó sus logros, como la celebración de los concilios, y alguna acción sobre el patrimonio. La mayor parte de la descripción de Blanch se centra en las confrontaciones entre el prelado y el capítulo y el prepósito, enfatizando los episodios violentos que se produjeron, algunos de ellos promovidos por los partidarios del arzobispo. Sin embargo, M. Marí, tributario en alguna de sus noticias de las de Blanch, registró mucho más sucintamente el conflicto con los canónigos, y ofreció una imagen menos partidista e incluso favorable a Benet de Rocabertí. En su archipiscopologio se registraron los logros en el terreno eclesiástico y la resolución pontifical en su favor en la disputa mencionada (Marí, 1999: 65-68).

Las acusaciones de J. Blanch explicitan que los canónigos habían sido despullats de tantes coses con los llevave lo archebisbe y aluden, sobre todo, a la pérdida de parcelas de poder (Blanch, 1985: 160). Por otra parte, advertía de que el rey había intentado mediar sin éxito en el momento de máxima confrontación. Refería también la provisión de un árbitro por parte del papa, capellán suyo, Nicolás de Terracina, para poner fin a la situación, cuya concordia había sido rechazada por el mitrado. El nombramiento nos es conocido por las fuentes vaticanas (Rodríguez de la Lama, 1976: doc. 185). Justamente, gracias a las misivas romanas se vislumbra que desde que Benet de Rocabertí accedió a la cátedra episcopal, se produjo un cambio trascendente con respecto a la articulación de los poderes de la sede tarraconense y al afianzamiento de su figura. De este modo, un conjunto de bulas promulgadas por Inocencio IV entre 1252 y 1254 llegaron a manos del arzobispo para respaldar su control sobre beneficios eclesiásticos, concediendo el permiso para la obtención de determinados impuestos eclesiásticos y para que pudiese retener las vacantes o la cámara (Quintana, 1987, II: docs. 823; 816 y 944; 929 y 824). Esta intervención habría sido uno de los motivos de confrontación reseñados por J. Blanch. En suma, el pontífice defendía las condiciones para una mejor financiación y afianzamiento de la autoridad del arzobispo en la administración de la sede, reforzando su mando y recursos.

Estas y otras situaciones convulsas están en el trasfondo de la confección del cartulario de Benet de Rocabertí, donde precisamente el soporte papal, 
como fuente de legitimidad, se puso de relieve a través de la compilación sistemática de las abundantes instrucciones romanas. La obra debería proporcionar cobertura jurídica en el contexto de las controversias mencionadas coleccionando diplomas acerca de las novedades sobre la organización de la sede y de las interacciones con el rey Jaime I, que, en definitiva, serviría para afirmar la autoridad arzobispal. En este sentido, el manuscrito aporta una radiografía de las cuestiones que la máxima dignidad quiso registrar, de su voluntad reformadora, de la defensa del despliegue de su poder, dependiente de las instrucciones papales, además de la atención a aspectos dominiales y de liderazgo orientados a fijar los derechos de la mitra. Estas últimas preocupaciones se fueron completando en décadas sucesivas. Por tanto, es indispensable estudiar este legado escrito desde el prisma de la elaboración de un recurso memorialístico, cuya intencionalidad de recapitular queda patente en cierta ordenación de las noticias, en los títulos en rojo que resumen buena parte de los documentos y en una elaboración cuidadosísima. No hay un orden cronológico estricto, pero la colocación de los diplomas, a menudo asociados y ordenados por temas, la existencia de dos grandes bloques y la descripción de los títulos reflejan que la elaboración del libro estuvo inspirada por criterios narrativos e intencionales. Es posible afirmar el arzobispo Benet de Rocabertí fue el primero en establecer una historia arzobispal, centrada en su mandato, para documentar sus acciones y afianzar su potestad, reforzada por la autoridad pontifical. Se elaboró una imagen que poco tenía que ver con la ofrecida por el canónigo J. Blanch siglos después.

En los primeros folios, el volumen recoge informaciones relativas a la proyección evangelizadora en Túnez y a la capacidad militar del arzobispo como señor regional. Se trasladaron los permisos para que algunos eclesiásticos ejercieran la cura animarum en el norte de África en 1253 y 1256 y para que la misión pastoral se desarrollase sujeta al metropolitano: Petrus Solerio fecit obedientiam domino archiepiscopo. ${ }^{12}$ La disponibilidad de efectivos militares en la región o Camp de Tarragona fue probablemente objeto de preocupación por Benet de Rocabertí y se registraron los contingentes de cada localidad y los señores del territorio, alguno dependiente directamente de los cargos del cabildo: iste sunt militie quod tenetur pro domino archiepiscopo Terrachonensis. ${ }^{13}$ 


\subsection{La autoridad pontifical y arzobispal en la organización eclesiástica y política}

Las bulas pontificales constituyen una parte significativa de los documentos copiados desde las primeras páginas, y a menudo de forma sucesiva. ${ }^{14}$ Muchas de ellas centraron y fueron cerrando problemas de disciplina de los eclesiásticos, así como finalmente sobre el afianzamiento de la autoridad arzobispal respecto a ellos y a las sedes sufragáneas. ${ }^{15}$ Por citar algunos ejemplos, el papa confirió al prelado el derecho de nombrar los curas y conceder beneficios vacantes en la diócesis y el de conceder beneficios y dignidades en la ciudad y obispado. ${ }^{16}$ Otras misivas papales le proporcionaron prerrogativas respecto a los eclesiásticos, como en términos de remisión; absolver a los excomulgados y a los clérigos concubinos, ir en contra de estos clérigos o consentirles residir en sus iglesias. ${ }^{17}$ Asimismo, se trasladaron algunas atribuciones religiosas sobre los laicos: Quod possit hereticos a carcere liberare. ${ }^{18}$ Otras instrucciones romanas más genéricas no implicaron directamente al mitrado, como la destinada a los predicadores super inquisitione hereticorum facienda in regno et dominio regis Aragonensis o un privilegio concedido a los eremitas de Hispania por Urbano IV. ${ }^{19}$

Los asuntos vinculados a la vida eclesiástica en los que intervino el arzobispo son muchos y dejó constancia de su poder preponderante en las diócesis sufragáneas, como en la de Calahorra, en la confirmación del obispo de Lleida, Berenguer de Peralta, y en la comissio facta abbati Populeti super ecclesia Sancte Tecle de Xativa. ${ }^{20}$ También reseñó cartas de obispos, como el de Tarazona, quien reclamaba una prebenda en la iglesia vacante de Calatayud. ${ }^{21}$ Otros instrumentos hacían patente la autoridad arzobispal, como la suspensión del obispo de la Seu de Urgell en 1254, o la revocación de bienes vinculados a la mesa arzobispal o diezmos en las iglesias propias y sufragáneas. ${ }^{22}$ Asimismo, fueron consignados aquellos sobre la convocatoria del capítulo provincial

14 AHAT, AB, f. 10v, 13rv y 15v; 33rv; 34rv, 36 rv, 37r, etc.

15 AHAT, AB, f. 23rv.

16 AHAT, AB, f. $8 v$ y f. 33 v.

17 AHAT, AB, f. 9r-v; f. 8v; f. 8r; f. 21v-22v; f. 9r.

18 AHAT, AB, f. 9v.

19 AHAT, AB, f. 19rv; f. 53v-54v.

20 AHAT, AB, f. 47r; f. 17rv; f. 11r.

21 AHAT, AB, f. 47r y su respuesta f. 47v.

22 AHAT, AB, 16r; f. 10r. 
por el papa y su desarrollo. ${ }^{23}$ Por otra parte, se puso de manifiesto las interferencias de los poderes laicos en aquello que debería ser competencia de la Iglesia, como la del rey cuando había revocado donaciones de iglesias, monasterios y religiosos que fuerant de reyalencho suo. ${ }^{24}$

En su conflicto con las dignidades del cabildo se cargó de argumentos canónicos y textuales para someterlas y recuperar el control sobre los beneficios, como aquellos que disfrutaba el camarero o acerca de los mismos durante las vacantes. Los nombramientos de los cargos también fueron registrados y amparados con otros traslados relativos a la intervención del pontífice en su provisión; y también se insertó la aceptación por parte de los beneficiarios de estos. $^{25}$

Algunos diplomas copiados cumplieron más bien con cierta función informativa, ejemplificadora (Kempshall, 2011: 243) y de contexto jurídico ya que no estaban destinados a la sede tarraconense. No obstante, formaron parte de un discurso de reivindicación de la autoridad de la Iglesia y, a veces, respecto a los poderes regios. En este sentido entendemos que se copiase la bula de Inocencio IV dirigida al emperador Federico II para que observase las constituciones sobre los herejes: Littera apostolica in qua mandatur observari constitutiones Frederici imperatoris contra heréticos edicte, ${ }^{26}$ bula que se copió a renglón seguido de otra misiva destinada a los herejes del «reino y dominio del rey de Aragón» según se ha mencionado. Se completó con otra carta de Alejandro IV en contra de la herejía en Italia, con otra destinada a los dominicos para que hicieran inquisición a los herejes de los territorios sujetos al rey de Aragón y otra con más detalles sobre la persecución. ${ }^{27}$

Otras situaciones del tablero político fueron objeto de registro dada su autoridad metropolitana, y eso explica que se copiase un instrumento a propósito de que el papa había recibido bajo su protección al rey de Navarra. ${ }^{28}$ Además, cabe prestar atención a la comunicación de Alejandro IV al arzobispo instándole a que mandase al rey Jaime I que desistiese de que su hijo Pedro se casara con Constanza de Sicilia, hija del príncipe Manfredo. ${ }^{29}$

AHAT, AB, f. 16v.

25 AHAT, AB, f. 12 r; f. 15 r; f. 63 r y $64 v$; f. $59 v$; f. $63 v-64 r$.

6 AHAT, AB, f. 19v-21r.

27 AHAT, AB, f. 25r-28v; f. 28v-29r; f. 29r-30v y más en 31r-32r.

28 AHAT, AB, f. 13r.

29 AHAT, AB, f. 39r-40r (1260) y sobre el mismo tema f. 42v-43r. 
El respaldo del papado servía para todo y fue un argumento central de legitimidad en la actividad del arzobispo, como hizo directa e indirectamente en cuanto al rey Jaime I. En este sentido, se explica que se trasladase el documento de Inocencio III sobre privilegium domini regis Aragonensis super coronatione sua et uxore sue en tanto que proporcionaba una autoridad al mitrado, que quería recordar y retener en un momento complejo de su relación con el monarca. ${ }^{30}$ Semejantemente se copiaron otros escritos sobre asuntos que concernían a la interacción directa del pontífice con el rey, como en relación con los votos para ir a Tierra Santa o sobre el uso de la moneda en el reino. ${ }^{31}$

\subsection{La afirmación del arzobispo frente al rey Jaime I}

Las tensiones, relaciones y acuerdos entre el prelado y el rey Jaime I se fijaron en la memoria escrita de este arzobispado, haciéndose acopio de documentación en el cartulario. Las primeras diferencias se habían producido en los años cuarenta, e incluso el monarca se había negado a renovar el juramento de fidelidad en 1242, manifestándose el conflicto de forma abierta desde 1255 (Bonet, 2011: 159). En este contexto, el códice reunió muchas de las cartas que Jaime I le mandó directamente sobre asuntos diversos, algunas destinadas a la universidad o a sus representantes en la ciudad reclamándoles que jurasen fidelidad al arzobispo, y otras dirigidas al mitrado, capítulo, prohombres, ciudadanos y hombres del Camp para que aceptasen a su representante en Tarragona. ${ }^{32}$ La disputa entre Benet de Rocabertí y Jaime I se resolvió en el compromiso alcanzado en Lleida; ${ }^{33} \mathrm{y}$, asimismo, en el volumen se registró el instrumentum quomodus rex Aragonensis in curia Ilerdensis jurauit et promisit domino Archiepiscopo et prelatis [...] Terrachonensis prouincie ipsos defendere, compilándose a este tenor otros actos jurídicos relacionados con la disputa entre ambos. ${ }^{34} \mathrm{Al}$ mismo tiempo, se trasladaron instrucciones papales dirigidas a Jaime I «porque había injuriado y molestado al prelado» en el contexto de las diferencias mantenidas entre ambos. ${ }^{35}$

30 AHAT, AB, f. 24rv.

31 AHAT, AB, f. 68rv; f. 50r.

32 AHAT, AB, f. 71r; f. 71v-72r; f. 73v-74r; f. 81r, 81v, 82r y 82v.

33 AHAT, AB, f. 74v-75r.

34 AHAT, AB, f. 73r; f. 75rv.

35 AHAT, AB, f. 37v y 38r-39 y Villanueva, XIX, doc. 154 
Por otra parte, en el códice se quiso recordar que Jaime I había recibido bajo su protección al prepósito y al capítulo en contra del prelado, ${ }^{36}$ había maniobrado a favor de los enemigos de Benet, e incluso había escrito al papa en contra de este. ${ }^{37}$ Asimismo, mantuvieron discordias por otros asuntos eclesiales. ${ }^{38}$ La narrativa mostraba las injerencias del rey en asuntos eclesiásticos y posiblemente este argumento contribuía a justificar, en parte, la confrontación con aquel y la necesidad de mantenerlo alejado de las cuestiones concernientes a la jurisdicción eclesiástica. A la luz de estos registros, resulta evidente que este fue uno de los temas que incidieron a la hora de confeccionar un texto que sirvió de apoyo para las reivindicaciones de la posición arzobispal frente al mandatario aragonés, recordando a su vez que las soluciones habían pasado por la intervención y el apoyo pontifical. Dada la importancia señalada de este antagonismo por uno de sus protagonistas, los escribanos de la sede fueron fieles a la tradición establecida por B. de Rocabertí y siguieron copiando los documentos referentes a estas controversias y soluciones. ${ }^{39}$

Una serie de ataques protagonizados contra la flota de Túnez por la armada del arzobispo en 1256 ocasionaron graves conflictos diplomático y mereció la reprobación del rey Jaime I, quien acusó a Benet de Rocabertí de haber roto la paz que mantenía con el rey de Túnez. Le culpó de haber asesinado la mayor parte de los musulmanes de las embarcaciones y de haber vendido los bienes o esclavos en Tarragona por treinta mil sueldos. Jaime I argumentó que la acción había minado su jurisdicción y había puesto en peligro las tropas que tenía en Túnez. En este contexto, seguramente se copió la bula pontifical de Inocencio IV en la que se legalizaba que los ciudadanos de Tarragona y de la diócesis pudiesen comerciar con los musulmanes y venderles 'cosas prohibidas': Quod possit absolvere illos qui portaberunt res prohibitas sarracenis [...] omnes illos de civitate ac diocesis et provincia Terrachonensis; ${ }^{40} \mathrm{o}$ los permisos sobre la predicación en Túnez concedidos por el arzobispo, aunque el volumen no se hizo eco del resto de sucesos. En cambio, en la fuente de la escribanía el Llibre de la Corretja de la decimosexta centuria se dejó constancia de las recla-

36 AHAT, AB, f. 76r,

37 AHAT, AB, f. 76r, 76v, 77r, etc.; f. 80r y 80v.

38 AHAT, AB, f. 87rv.

39 AHAT, LLc, doc. 32, 33, 36, 37, etc. Y sobre las soluciones de Alejandro IV; LLc, doc. 44, 45, 46; y de Clemente IV, LLc, doc. 47, 48 y 49.

40 AHAT, AB, f. 10r, registrada en los fondos vaticanos, Quintana, 1987, II: doc. 818. 
maciones del monarca respecto de los daños ocasionados por el mitrado al mandatario tunecino. ${ }^{41}$

\subsection{El poder dominial de la sede y los juramentos de fidelidad}

Otros documentos regios fueron también objeto de traslado en esta memoria arzobispal, alguno afectaba únicamente al dominio de Tarragona, y en otros no había intervención del prelado (1229). ${ }^{42}$ Esto se debía al papel que el rey tenía en el dominio tarraconense, que fue objeto de divergencias y concordias con el arzobispo, ${ }^{43}$ que estuvieron presentes en otras compilaciones de carácter memoralístico de la sede ${ }^{44}$ y también se trasladaron en el Índex Vell del siglo XVII (Ramon, Ricomà, 1997: 117, 162, etc.). Por otra parte, en el LLibre de la Corretja se registraron algunos de los juramentos de fidelidad prestados por el rey de Aragón al arzobispo dada la dependencia vasallática que le debía en virtud del dominio de Tarragona, así como algunos requerimientos hechos por los arzobispos a los titulares del reino aragonés para el cumplimento del juramento. ${ }^{45}$ Sirva de testimonio el juramento de Jaime II en 1292 con los siguientes términos: dominus Jacobus Dei gratia rex Aragonensis [...] iuravit Roderico archiepiscopo Tarrachona fidelitatem pro civitate et terminis Tarracone. ${ }^{46}$

Siempre en relación con la reivindicación del ejercicio de la máxima autoridad de Benet de Rocabertí, especialmente frente a otros señores, en el cartulario se fueron introduciendo documentos sobre juramentos de fidelidad de otros dependientes, como los de Bernat de Castelcir en 1266 o de Elisenda de Calder, explícitamente pro feudo [...] tenet per episcopo..$^{47} \mathrm{El}$ interés por reunir por escrito las dependencias vasalláticas formó parte de la tradición memorialística de la sede tarraconense, presente ya en el códice $\mathrm{AB}$, y que copió los juramentos de fidelidad al arzobispo en el Llibre de la Corretja, amén de los mencionados que le prestó el monarca. Se trasladaron una serie de juramentos de fidelidad que hicieron miembros acomodados de las sociedades de la región cuando este alcanzaba el cargo. Eran beneficiarios de feudos o posesiones procedentes de la mitra, como algunas élites locales o familias destacadas

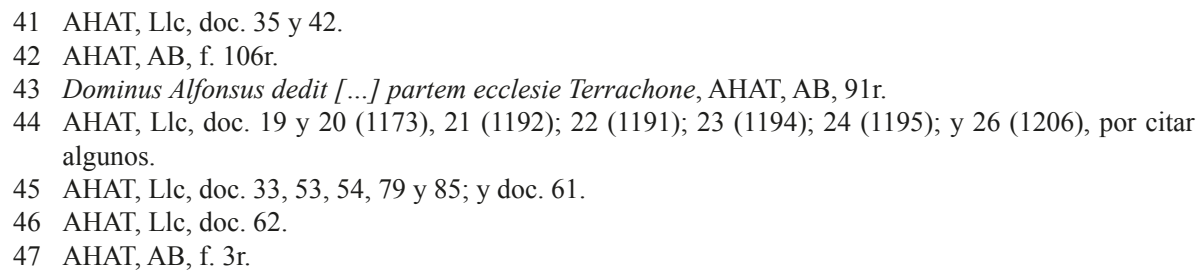


de la ciudad..$^{48}$ Además, desde el último cuarto del siglo XIII y hasta el XV, el mitrado obtuvo los juramentos de fidelidad de algunas localidades del Campo en calidad de señor, como Montroig, Cambrils, Valls, el Pla de Santa María, Vila-seca, o incluso de los ciudadanos de Tarragona, que serían registrados en el Índex Vell (Ramon, Ricomà, 1997: 216, 217, 218, etc).

Además de los asuntos vistos sobre los desencuentros del prelado con el cabildo y el rey Jaime I o de la insistencia en la estrecha vinculación del arzobispo con el papado, el manuscrito tenía la voluntad de historiar los jalones en los que se habían ido estableciendo las relaciones de poder y en torno a las propiedades en la ciudad y el Camp de Tarragona. En ese sentido, se recogió la noticia - una de las primeras del volumen-, sobre la sentencia pronunciada por el arzobispo Pedro de Albalate en 1248 respecto el proceso mantenido entre los vicarios o veguers de Tarragona y el prepósito. ${ }^{49}$ Es importante observar la voluntad de 'historiar' del códice, que reunió instrumentos acerca de la historia de las relaciones feudales de la ciudad y Camp de Tarragona, algunas incluso ajenas a la intervención del prelado. ${ }^{50}$ Esta documentación corresponde fundamentalmente a la segunda parte que contiene cerca de un centenar de diplomas con datos sobre la formación y gestión dominial. Se trata de un compendio de donaciones, compraventas, composiciones, establecimientos rurales y urbanos, y censos que afectaban a una serie de lugares del Camp de Tarragona del señorío arzobispal o de alguno de los cargos de la sede como Riudoms, Montroig, Cambrils, u otros menores como El Morell, La Masó, o también en Barcelona y Tarragona. Según se ha visto, un índice inicial permitía localizar las noticias, resumidas bajo epígrafes como: Censualia que archiepiscopus habebat in Monterubea [... ] et in Alcoverio. $^{51}$

\section{A modo de conclusión}

La memoria arzobispal tarraconense en la plena edad media nos ofrece las claves para comprender cómo la afirmación de la figura del arzobispo se dotó de una amplia construcción ideológica, que a su vez se entrelazó y se confron-

\footnotetext{
48 AHAT, Llc, doc. 51, 73 y 77 en 1272, 1309 y 1317.

49 AHAT, AB, f. 2v.

50 AHAT, AB, f. 120rv (1151); 149rv (1158); 149r (1159); 126v-127r (1159), por mencionar algunos ejemplos y las relaciones dominicales o patrimoniales, no siempre relativas a la sede: AHAT, AB, f. 126v (1169), 149v-150r (1183), 124v-125r (1187), 121v (1203), 154v (1286), 91r (1290), 92v (1290), etc.

51 AHAT, AB, f. IIIr.
} 
tó, en ocasiones, con otras imágenes generadas desde la elaboración de otros relatos. En este sentido, la legitimidad de la mitra y de su titular radicaban en la tradición del primer cristianismo, en su sacralidad martirial, en la conexión directa con la santa sede, en el dominio patrimonial y señorial de Tarragona y región, en la posición preeminente frente a reyes y poderes laicos, y también respecto a eclesiásticos e incluso a otros obispos. El poder del arzobispo quedó arropado en la tradición impulsada y difundida desde la escribanía de la sede, que se valió de un conjunto de imágenes icónicas que se convirtieron en un relato de legitimidad, valorización y autoridad (Hobsbawn, Ranger, 1983: 9 y Kempshall, 2011).

La restauración fue un hito en la formulación de un ideario sobre dicha potestad, con referentes fijados en los orígenes del primer cristianismo y que atribuyó un halo de santidad a los mitrados Oleguer y Hug de Cervelló reaccionando, así, a los tiempos difíciles que marcaron sus episcopados. Ya en el siglo XIV, culminó la idea de la santidad arzobispal reconocida en Juan de Aragón, que conectó con la sacralización de su estirpe, fortalecida desde la cátedra tarraconense. Por otra parte, la situación poco clara respecto del cargo y la figura del obispo electo o sacristán de Girona, Guillem de Montgrí, advierte de una realidad compleja en el liderazgo de la cátedra tarraconense. Las fuentes, más o menos contemporáneas y las de cuño historiográfico arzobispales se fijaron sobre todo en la transmisión de los derechos sobre Ibiza, siendo menos precisas en cuanto a su relación con la sede. Sólo poco después de mediados del siglo XIII, y para superar también otra etapa de conflictos que afectaron a la gobernanza de la misma sede, el prelado reescribió la historia de su mandato con el objetivo de legitimar su autoridad y apuntalar medidas de cierto calado reformista. El códice promovido por Benet de Rocaberí terminó albergando un recuento de las relaciones de poder eclesiales, políticas y feudales, así como de la formación y evolución de determinados patrimonios, siempre bajo la protección y de la mano del pontificado.

\section{Referencias}

\subsection{Referencias de fuentes archivísticas}

Archivo Histórico Archidiocesano de Tarragona (AHAT)

Llibre de la Corretja, siglo XVI (Llc)

Armario de la Mitra, Cartulario de Benet de Rocabertí (códice AB), siglos XIII-XIV (AB) 
Índex de los índices més moderns que es troben en lo arxiu de il.lustríssim senyor arquebisbe de Tarragona a 10 de juny de 1675

Marí, Marià, Thesaurus sancte metropolitanae ecclesiae tarraconensis, anno MDCCLXXXIII, 1783 (manuscrito)

Archivo Histórico de Tarragona (AHT)

Pergaminos: 57

Archivo Departamental de los Pirineos Orientales, Perpiñán (ADPO)

Liber feudorum $C$ (LFc), folios 42r, 42v, 61r, 61r-v, 64r-v, 87v-88r, 88r-v y 89r-v. Archivo de la Corona de Aragón (ACA)

Registros de Cancillería (RC), volumen 3.

\subsection{Referencias bibliográficas}

AURELl, Martín (1999), «Esclavage et croisade dans la 'Vie et miracles' de l'évêque Oleguer (1137) de Barcelona.» En Hommage à Pierre Bonnassie. Toulouse, Debax, 87-91.

Batlle i Huget, Pere (1946), Los tapices de la Catedral Primada de Tarragona. Tarragona: Sindicato de Iniciativa de Tarragona.

BLANCH, Josep [1985], Arxiepiscopologi de la santa església metropolitana i primada de Tarragona. Tarragona: Diputació de Tarragona. 2 vols. Transcripción y prólogo a la edición de 1665 de Joaquim Icart.

BARÓ I QUERALT, Xavier (2009), La historiografía catalana en el segle del Barroc (1585-1709). Barcelona: Publicacions de l'Abadia de Montserrat.

Bonet Donato, Maria y Amancio Isla (2011), Tarragona medieval. Capital eclesiàstica i del Camp, en Història de Tarragona. En Montserrat Duch, ed., Història de Tarragona, Lleida: Pagès Editors.

Bonet Donato, Maria (s. a.) «Benet de Rocabertí.» En Diccionario biográfico electrónico de la Real Academia de la Historia:_http://dbe.rah.es/biografias/71144/ benet-de-rocaberti

Chibnall, Marjorie (ed.) (1978), The Ecclesiastical History of Orderico Vitalis. Oxford: Oxford University Press. Vol. 6.

ESCANDELL I DARANES, Josep Maria (2010), «Guillem de Montgrí, sagristà major de Girona i arquebisbe Tarragona (segles XII-XIII) i la conquesta de Girona.» En Narcís Figueras y Pep Vila, ed., Miscel.lània en honor de Josep Maria Marquès. Barcelona: Publicacions de l'Abadia de Montserrat, 119-129.

ESPAÑOL BERTRAN, Francesca (2016-18), «El sepulcre de Joan d'Aragó a la catedral de Tarragona. Un aixopluc de marbre en el context de la 'Beata Stirps'», Lambard: Estudis d'art medieval, 27: 153-186.

FACI LACASTA, Javier (1991), «Algunas observaciones sobre la restauración de Tarragona.» En Miscel·lània en homenatge al p. Agustí Altisent. Tarragona: Diputació de Tarragona, 469-485. 
FlóREZ, Enrique (1770), España Sagrada. Contiene las memorias de las antiguas Eclesiásticas de la Santa Iglesia de Tarragona. Madrid: Antonio Marín.Volumen $\mathrm{XXV}$.

FLÓREZ, Enrique (1775), España Sagrada. Madrid: Pedro Marín. Volumen XXIX. «Vita Sancti Ollegarii.» (1143 post).

FOnT RiUs, Josep María (1969), Cartas de población y franquicia de Cataluña. Madrid-Barcelona: Consejo Superior de Investigaciones Científicas, I.

FONT I RIUS, Josep Maria (1966), «En torn a la restauración cristiana de Tarragona. Esquema de la seva ordenació jurídica inicial.» Boletín Arqueológico, 93-96: 85105.

GoÑI GAZTAMBIDE, José (2010), «Una bula de Juan XXII sobre la división de la provincia de Tarragona.» Príncipe de Viana, 251: 717-721.

HoBSBAWN, Eric (1983), «Introduction: Inventing Traditions.» En Eric Hobsbawn y Terence Ranger, ed., The Invention of Tradition . Cambdridge: Cambridge University Press, 1-14.

ICART, Pons d' (1572), Catalogo del Archebisbes que son estats de la Metropolitana Església y antiquissima ciutat de Tarragona. Tarragona.

JORDÀ FERNÁNDEZ, Antoni María (2006), Història de la ciutat de Tarragona. Tarragona: Cossetània.

KeMPSHALl, Matthew (2011), Rhetoric and the Writing of History. Manchester: Manchester University Press.

MANSILlA, Demetrio (1955), La documentación pontificia hasta Inocencio III. Roma: Instituto Español de Estudios Eclesiásticos.

MC CRANK, Lawrence (1976-77), «La restauración eclesiástica y reconquista en la Cataluña del siglo XI. Ramon Berenguer I y la sede de Tarragona.» Analecta Sacra Tarraconensia, 49-50: 5-39.

MC CRANK, Lawrence (1977), «Restauración canónica e intento de reconquista de la sede Tarraconense, 1076-1108.» Cuadernos de historia de España, 61-62: 145-245.

MC CRANK, Lawrence (1978), «The Foundation of the Confraternity of Tarragona by Archbishop Oleguer.» Viator. Medieval and Renaissance Studies, 9: 157-178.

MARí, Marià (1999), Exposició cronológico històrica dels noms i dels fets dels arquebisbes de Tarragona. Tarragona: Diputació de Tarragona, II. Edición de Josep Maria Escolà [1783].

MARQUÈS I CASANOVAS, Jaume, (1970), «Guillermo de Montgrí.» Revista de Girona, 50: 28-31.

MENCHON BES, Joan et alii (2007), La catedral de Tarragona. In sede, 10 anys del pla director de restauració. Tarragona: Arola.

MiReT I SANS, Joaquim (1918), Itinerari de Jaume I el Conqueridor. Barcelona: Institut d'Estudis Catalans.

MORELLÓ BAGET, Jordi (2018), Estudi sobre la genèsi d'un senyoriu camptarragoní: Riudoms i el seu terme, des dels seus orígens fins a mitjan segle XIV. Edición del autor. 
MORERA I LlaURADÓ, Emili [1897], Tarragona cristiana. I. Tarragona: Diputació de Tarragona, 1981.

Morera I LlaURADÓ, Emili [1899], Tarragona cristiana. II. Tarragona: Diputació de Tarragona, 1954/1982.

PEREA SIMÓn, Eugeni (2010), Historiografia religiosa de l'arxidiòcesi de Tarragona (1606-2007). L'estat de la qüestió. Barcelona: Abadia de Montserrat.

PÉREZ MARTINEZ, Meritxell (2012), Tarraco en la antigüedad tardía. Cristianismo y organización eclesiástica (siglos III a VIII). Tarragona: Arola.

QuintanA PRIETO, Augusto (1987), La documentación pontificia de Inocencio IV (1243-1254). Roma: Instituto Español de Historia Eclesiástica. 2 vols.

RECASENS COMES, Josep Maria (2016), La fundació de Tarragona en la historiografía. Tarragona: Publicacions de la Universitat Rovira i Virgili.

SÁNCHEZ REAL, José (1954), El archiepiscopologio de Luis de Icart. Tarragona: Real Sociedad Arqueológica de Tarragona.

SÁNCHEZ REAL, José (1951), El brazo de santa Tecla. Tarragona: Imprenta Sugrañes.

SERRA I VILARÓ, Joan (1934), Les pintures murals de la seu primada de Tarragona. Tarragona: Tallers Tipogràfics Sucursal de Torres \& Virgili.

SolDEVILA, Ferran, ed. (1983), Les quatre grans cròniques. Jaume I. Bernat Desclot. Ramon Muntaner. Pere III. Barcelona: Selecta.

SUREDA I JUBANY, Marc (2010), «La memòria escrita d'un clergue il·lustre. Documents de Guillem de Montgrí.» Narcís Figueras y Pep Vila, ed., Miscel.lània en honor de Josep Maria Marquès. Barcelona: Publicacions de l'Abadia de Montserrat: 197-211.

RAMON, Salvador y F. Xavier RICOMÀ, eds., (1997), Index Vell.Índex dels documents de l'arxiu de l'Arquebisbe. 1. ${ }^{a}$ Part. Tarragona: Diputació de Tarragona.

RODRÍGUEZ DE DE LAMA, Ildefonso (1976), La documentación pontificia de Alejandro IV (1254-1261). Roma: Instituto Español de Historia Eclesiástica.

VILlANUEVA, Jaime L. (1850-1852), Viaje literario a las iglesias de España. XIX. Madrid: Imprenta de la Real Academia de la Historia. 